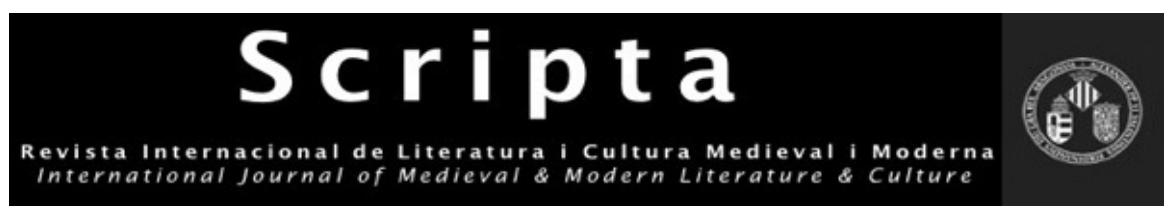

\title{
Escriure poesia al convent entre la devoció i l'obediència. Primera aproximació a un manuscrit femení del segle XVIII
}

\author{
Writing Poetry in the Convent Between Devotion and Obedience. A \\ First Approximation to an 18th-Century Feminine Manuscript
}

\author{
VERÒNICA ZARAGOZA \\ veronica.zaragoza@udg.edu
}

Universitat de Girona

\begin{abstract}
Resum: El manuscrit que ens disposem a donar a conèixer és un tresor documental interessantíssim per abordar l'estudi dels usos poètics de les dones d'època moderna als territoris de parla catalana, no només pel nombre de composicions recuperades d'una mateixa autora (un total de 53 poesies espirituals, no catalogades i desconegudes fins ara) sinó perquè es tracta d'un dels pocs autògrafs femenins accessibles per a la recerca. La inexistència de treballs dedicats exclusivament a la poesia femenina d'època moderna al panorama català, ens obliga necessàriament a iniciar el treball amb una primera part introductòria dedicada a qüestions relatives als usos poètics de les dones dels segles XVIXVIII, tot centrant-nos en algunes autores de l'àmbit conventual, al qual pertany el manuscrit objecte d'estudi. En la segona part del treball, ens centrem particularment en l'anàlisi i estudi del manuscrit. Així doncs, en una primera aproximació, descrivim el contingut del quadern, íntegrament en castellà, que recull composicions de caire espiritual i devot, i esbossem les dades biogràfiques de l'autora, la religiosa dominica sor Eulària Teixidor. Tot partint dels interessants estudis apareguts en els darrers anys sobre la literatura conventual femenina, intentem vincular aquest manuscrit amb la variada producció monàstica escrita per nombroses religioses de l'època sota manament del confessor.
\end{abstract}

Paraules clau: Estudis de gènere; Literatura femenina conventual; Poesia religiosa; Eulària Teixidor; Manuscrit

Abstract: The manuscript that we are presenting is a fascinating and highly valuable document to study the catalan women poetry in the Modern Age, not only because of the number of recovered pieces from the same author (53 unknown spiritual poems not yet catalogued), but also because it is one of the few feminine manuscripts accessible for research. The lack of works exclusively dedicated to the feminine poetry in the Catalan-speaking countries in the Modern Age compels us to start the work with some general considerations concerning poetical works of women in the 16th-18th centuries, focusing on the conventual literature, which the manuscript belongs to. As a first approximation, we describe the content of the manuscript, which is entirely written in Spanish, that includes spiritual and pious compositions and we provide some biographical information of the author, the dominican Sister Eulària Teixidor, so far undiscovered. Relying on the recent interesting studies published on Women's Monastic Literature, we try to establish connections between this manuscript and the varied monastic literature, produced by numerous nuns in this period under the order of the confessor.

Key words: Gender Studies; Women's Monastic Literature; Religious Poetry; Eulària Teixidor; Manuscript 


\section{Verònica Zaragoza. Escriure poesia al convent: entre la devoció i l'obediència. Primera} aproximació a un manuscrit femení del segle XVIII

L'absència de treballs dedicats exclusivament a la poesia femenina d'època moderna al panorama catalanoparlant, ens obliga necessàriament a anar per parts abans d'abordar la descripció del manuscrit que avui exhumem: així doncs, en primer lloc, iniciarem el treball amb una introducció general centrada en qüestions relatives als usos poètics de les dones als territoris esmentats durant els segles XVI-XVIII, tot centrant-nos en algunes autores de l'àmbit conventual, al qual pertany el manuscrit objecte d'estudi. A continuació, en la segona part del treball, es presenta el manuscrit i se'n dóna a conèixer l'autora, fins ara anònima. Malgrat que es tracta d'una divisió en dues parts aparentment inconnexes i ben diferenciades, creiem que és necessari apuntar, prèviament, la problemàtica que acompanya l'estudi dels textos poètics femenins a casa nostra i contextualitzar, amb la revisió d'obra d'altres autores, les circumstàncies d'escriptura en què s'emmarca el volum que donem a conèixer en la segona part, atés que es tracta d'un camp d'investigació encara molt desconegut i intransitat per la crítica. Sols així podrem copsar la riquesa i excepcionalitat d'aquest llegat que recuperem després de segles de silenci.

Ara bé, amb el poc espai de què disposem i atenent que es tracta d'un manuscrit desconegut i de gran extensió, en aquest estudi pretenem fer-hi només una primera aproximació: proporcionem breument les dades biogràfiques de l'autora, així com les circumstàncies d'escriptura intramurs, per passar, en darrer lloc a l'anàlisi d'algunes composicions per comprovar de quina manera sintonitzen amb la resta de testimonis poètics que coneixem. Posposem per a futurs treballs l'anàlisi de qüestions més concretes, relacionades amb la temàtica de les composicions o aspectes interpretatius, relacionats amb la devoció, pietat i espiritualitat manifestades per la religiosa.

\section{Introducció}

En els darrers anys, el tema de la literatura femenina a l'edat moderna ha experimentat un veritable boom historiogràfic als territoris de parla castellana (amb una atenció destacada a l'Amèrica Llatina), que ens ha permés de conèixer amb més detall les circumstàncies de la creació literària femenina a l'època moderna, les autores i la tipologia textual conreada; l'increment dels estudis ha estat, sens dubte, afavorit pels treballs de recerca i catalogació dels textos que des de fa dècades van duent-se a terme en aquests territoris. ${ }^{1}$ Pel que fa a l'àmbit lingüístic català, malgrat que en les darreres dècades

\footnotetext{
* El present treball forma part d'un projecte doctoral en curs, que té com a eix fonamental la literatura femenina a l'àmbit català (ss. XVI-XVIII), centrat especialment, en el gènere poètic. He d'agrair les orientacions proporcionades en la recerca per Pep Valsalobre, Eulàlia Miralles, Albert Rossich, Eulàlia d'Ahumada i M. Mercè Gras. Advertisc que, pel que fa a la transcripció dels textos, he respectat l'ortografia del model exceptuant-ne l'accentuació, la puntuació i l'ús de majúscules i minúscules, que han estat regularitzades seguint els criteris actuals de transcripció; respecte a les composicions poètiques, oferisc els textos regularitzats (Blecua \& Serés dir. 2008) però no les rúbriques, que han estat transcrites tal com consten als originals. Agraïsc a Eulàlia d'Ahumada la notícia del manuscrit, així com a la comunitat de religioses de Sant Benet i el SAF (Servei d'Arxius de la Federació Catalana de Monges Benedictines: http://www.federaciobenedictines. cat/wordpress/?page_id=7) -amb la constant dedicació de les arxiveres Coloma i Irene Brugués- haver-me'n facilitat la consulta. Igualment, he d'agrair també a les religioses del monestir de Montsió d’Esplugues de Llobregat, l'accés al seu arxiu, així com també les facilitats proporcionades en la localització de la documentació i l'ajuda desinteressada de la seva arxivera Leonor Parreu i Dalmases, que ha dedicat un treball ampli al fons de la comunitat: «L'arxiu monàstic de Santa Maria de Montsió: estudi, representació formal i ordenació de la col lecció de pergamins (1264-1784)», actualment en procés de publicació per la Fundació Noguera.
} 
s'ha vist afavorit per una certa revaloració del tema i hi han anat apareixent (en un degoteig lent però constant) diverses contribucions dedicades a recuperar i a estudiar l'obra femenina d'època moderna -independentment de la llengua literària emprada - (un estat de la qüestió a Miralles/ Zaragoza 2012), la recerca encara s'hi troba en un estat bastant embrionari. Sens dubte, una de les problemàtiques amb què ens trobem a l'hora de fixar i estudiar les aportacions de les dones en el camp de creació literària, és el de la localització d'un material de variada circulació: generalment manuscrit i, en alguns casos, imprés en edicions antigues ben disperses. Per aquesta raó, molts cops l'estudi en aquest àmbit esdevé una tasca feixuga i complicada, entrebancada per la dispersió textual i la precarietat d'unes fonts (moltes d'elles, destruïdes o desaparegudes) ${ }^{2}$ que permeten de copsar només parcialment un fenomen literari en què les dones dels territoris catalanoparlants (sobretot les religioses, en paral lel amb les de les terres veïnes) hi van contribuir més del que ha estat recollit.

Així doncs, malgrat els intents d'establir un corpus textual femení i els avenços assolits fins ara, al panorama lingüístic català, encara manquen treballs que ajuden a traçar l'activitat literària femenina al llarg dels segles moderns, amb la individualització de les autores, de les quals actualment tenim un coneixement desigual, ja que algunes han estat bastant estudiades com ara la prolífica sor Hipòlita de Rocabertí (Barcelona, 1551-1624) (Ahumada 2013) i d'altres ens són completament desconegudes. Hi manquen també estudis que aporten llum a espais prolífics intransitats, com és el de la creació poètica, actualment un camp obert de recerca poc tractat. Tot i que s'havien anat constatant evidències del gust de les dones de parla catalana per la poesia ${ }^{3}$ el tema no havia despertat fins ara l'atenció requerida en aquests territoris ${ }^{4}$ i només en els darrers anys hi han aparegut algunes iniciatives dedicades a esclarir alguns aspectes relacionats amb el fenomen poètic femení del panorama modern catalanoparlant, que requereixen com a tasca prèvia, necessàriament el rescat d'alguns textos encara desconeguts (Zaragoza 2012). I és que, actualment, són molt escasses les edicions modernes realitzades sobre la poesia femenina: comptem amb l'edició de l'obra catalana (Vida espiritual, comentari lul lista $i$ cobles) de la mallorquina sor Anna Maria del Santíssim Sagrament (Valldemossa, 1649-Palma, 1700) (Trias 1988), l'edició dels goigs catalans atribuïts a la religiosa del monestir de Santa Maria de Vallbona sor Jerònima de Boixadors (?-1562) (Piquer ed. 1986) i l'edició de la poesia de la castellonenca Maria Egual (Castelló de la Plana, 1655- València, 1735) (Mas/ Vellón 1997). Més enllà d'aquestes edicions, cal avançar en el coneixement de l'activitat poètica de les dones

1BIESES: http://www.uned.es/bieses/, que recull algunes autores dels territoris catalanoparlants.

2 La necessitat d'exhumar i d'editar l'obra femenina per exposar-la a la revisió de la crítica, s'evidencia amb més força si considerem la quantitat de textos femenins inèdits, de caire memorialístic, escrits i conservats sense propòsits literaris en els furs privats de la llar i dels convents, que ens ha revelat recentment la investigadora Eulàlia Miralles (2013).

3 Rubió va dedicar unes línies a Adriana Cabanyes i Sinisterra, participant d'un certamen poètic celebrat en les festes immaculistes de 1618 a Barcelona i guanyadora del segon guardó de la categoria de versos catalans, en considerar que les quartetes presentades eren «força fàcils i molt superiors per llur doctrina teològica als versos pèssims de Lisardo [guanyador del primer premi]» (1984-86: 132).

4Com a mostra, en una de la primeres antologies sobre la poesia femenina en català, els segles moderns hi són considerats «segles de silenci», raó per la qual no s’hi recull cap autora del període (Albert/ Matheu/ Saltor/ Sala/ Torras 1975: 6).

SCRIPTA, Revista internacional de literatura i cultura medieval i moderna, núm. 1 / juny 2013 / pp. 333-361 ISSN: 2340-4841 · doi:10.7203/SCRIPTA.1.2590 
modernes, que es veurà incrementat a mesura que progressem en la recuperació i localització dels textos conservats, considerant-hi també les obres que ara com ara resten desaparegudes i d'altres de què només tenim constància per algunes referències documentals; però, especialment, amb la troballa d'obres que, sense catalogar, han restat manuscrites i oblidades durant segles en biblioteques diverses, arxius institucionals o, sobretot, conventuals, com és el cas del manuscrit que avui ens ocupa.

Abans de centrar-nos en el dit manuscrit, és interessant d'aturar-nos en una de les nostres autores més conegudes, sor Gertrudis d'Anglesola (València, 1641-1727), per incidir en la necessitat d'una exhaustiva tasca de documentació, d'exhumació de les fonts a fi de poder integrar totes les peces d'aquest trencaclosques que suposa l'acte de creació literària femenina a l'època moderna. Entre la documentació provinent dels fons procedents de les desamortitzacions eclesiàstiques dipositats a l'Arxiu del Regne de València (relativa als ordes i a les congregacions religioses, tant masculines com femenines), ${ }^{5}$ hem ubicat la documentació del Reial Monestir de Gratia Dei o de la Saïdia, de la ciutat de València. Entre els documents pertanyents a aquesta antiga comunitat de religioses cistercenques, majoritàriament de caire administratiu-econòmic, hem descobert un material valuosíssim inèdit: un conjunt epistolar relatiu a l'abadessa i famosa mística de l'esmentada comunitat, la venerable Gertrudis d'Anglesola (Herrero 2009: 41-42). El lligall «Cartas del canónigo D. Manuel Catalán a D. Gertrudis Anglesola, religiosa del monasterio, sobre espiritualidad», conté unes 55 cartes que daten del 1677 fins al 1683 (d'altres sense data), que haurien estat copiades de la correspondència espiritual establerta entre la virtuosa sor Gertrudis i l'esmentat Catalán. Ara bé, no només s’hi troben les missives enviades pel canonge sinó també hi ha la transcripció d'algunes cartes procedents de la religiosa; ${ }^{6}$ cartes fins ara desconegudes, segons les notícies de què disposem, que ens aportaran nova llum sobre aquesta escriptora virtuosa i obriran noves vies en l'esclariment de les circumstàncies de creació literària conventual.

Respecte a aquesta mateixa religiosa, cal recordar que pel que fa a les obres atribuïdes, sabem que el seu confessor Josep de San Juan de Mata li va ordenar que escrivís detalls de la seva vida interior, així com una Protestación amb les oracions que pronunciava al llarg del dia i d'altres; material escrit en castellà que va ser utilitzat pòstumament en l'escriptura dels sermons fúnebres impresos dedicats a la religiosa (Miguel [1727] i Ortí 1728) i, posteriorment, a la seva Vida (Ortí 1743). Aquesta biografia, que inclou alguns fragments de l'obra de la religiosa, reflecteix el model hagiogràfic estereotipat de l'època, basat en l'excel lència de les virtuts religioses de Gertrudis perquè fos presa com a model de santedat a imitar per a les companyes de professió. Amb tot, allò que ens interessa de remarcar aquí és que més enllà del llegat que se li ha atribuiit, ens consta que la religiosa també es va dedicar al conreu de la poesia

5 ARV. Clero. M a Cruz Farfán Navarro, Real Monasterio de Gratia Dei o Zaidía de Valencia: Catálogo de sus fondos ( 1253 1839), València, [1993], f. 25.

6 ARV. Clero. Llib. 2950, 55 ff. 310 x 215 mm (Cob. Perg.). Entre aquests papers, trobem també els escrits d'una religiosa que manifestava, a través d'uns anomenats desafíos, els seus desitjos de perfeccionament religiós i que amplien la tipologia textual femenina coneguda: «[...] siete papeles de sor María Teresa Rodrigo, religiosa de la obediencia del convento de la Zaidia, la que también desafiava a D. Gertrudis cada mes, a quien se esmeraría más en el egercicio de alguna particular virtud».

SCRIPTA, Revista internacional de literatura i cultura medieval i moderna, núm. 1 / juny 2013 / pp. 333-361 ISSN: 2340-4841 · doi:10.7203/SCRIPTA.1.2590 
espiritual i devota, com tantíssimes religioses de l'època, malgrat que la crítica actual no ho ha recollit; omissió aquesta motivada segurament pel fet que es tracta d'obra desapareguda que només coneixem a través de les asseveracions del seu biògraf, que declarava a la Vida impresa que la venerable:

Solía clamar con mucha frecuencia a su divina magestad por amor y le dezía con afectuosos suspiros: «Déxate amar, bondad infinita; déxate hallar. Sé que me dirás, Señor que yo no tengo la culpa u que falta por mí, pero ya sabes, Señor, que soy miserable, flaca y toda inmunda». Repetía muchas vezes y enseñava a todos estos mal formados pero fructuosíssimos versos, en quienes no se ha de atender a las leyes de el arte, porque aunque están sin poéticas reglas, respiran fervorosos afectos (Ortí 1743: 260-261). ${ }^{7}$

Ortí ens hi parla de la poesia devota de sor Gertrudis, tot emprant els tòpics acostumats utilitzats pels biògrafs que menyspreaven l'obra femenina i la situaven en l'àmbit afectuós, expressiu, més que no pas en l'intel lectual o literari: segons ell, es tractava d'uns versos «mal formats», desproveïts de «leyes de el arte» $\mathrm{i}$ «sin poéticas reglas», però «fructuosíssimos», perquè anaven destinats a la formació de l'ànima. A continuació, Ortí transcriu nou versos que haurien pertangut a sor Gertrudis (Inc.: «Amemos à Dios y Bàstanos...» 1743: 261) i que ens permeten copsar el to de la seva lírica. Malgrat que, com ja hem dit, no ens n’ha arribat cap altre testimoni i per bé que la notícia ens arriba a través d'aquesta minsa al lusió que no ha estat recollida pels estudis que s'hi han dedicat, aquesta constatació és molt important ja que ens permet connectar aquesta religiosa amb el grup nombrós de místiques que, al costat d'altres manifestacions literàries (fonamentalment les Vides espirituals, els relats de favors, tractats religiosos, etc. però no solament) també van recórrer al llenguatge poètic d'expressió amorosa traslladada al diví, com a fuga d'escapament i com a activitat integrada en els exercicis místics i contemplatius conventuals (Baranda 2005: 92).

\section{El binomi literatura femenina-literatura conventual}

Tal com ja ha estat estudiat, el fenomen de l'escriptura femenina al territoris catalanoparlants, comença a despuntar amb algunes poques autores a partir del segle XVI, gràcies especialment als avanços que havien generat les idees humanistes (Bellveser coord. 2012) i a l'aparició de la impremta, que tal com apunten alguns investigadors, si no va comportar un augment del públic lector sí que en va incrementar el ventall de possibilitats incloent-hi el públic lector femení (Escartí 2011, tot citant a Philippe Berger). Ara bé, és a partir del segle XVII, que el fenomen de la literatura escrita per dones es desborda quan l'escriptura conventual i l'escriptura femenina esdevenen un binomi indissoluble, vertebrat per la proliferació de les monges o beates que escriuen per encàrrec del confessor, tal com s'esdevingué a l'Europa Catòlica (inclosa la Nova Espanya), sotmesa al control espiritual post-tridentí (Amelang 1990, Poutrin 1995, Herpoel 1999, Ferrús 2004, Ahumada 2010, Herrero 2010, entre d’altres). L'espai

7 El subratllat és meu.

SCRIPTA, Revista internacional de literatura $i$ cultura medieval $i$ moderna, núm. 1 / juny 2013 / pp. $333-361$ ISSN: 2340-4841 · doi:10.7203/SCRIPTA.1.2590 
conventual, dotat molts cops de riques biblioteques, ${ }^{8}$ esdevingué un autèntic àmbit de promoció de lectura i escriptura femenina, possibilitava a les religioses una instrucció bàsica adreçada als exercicis devots i l'ofici diví (llegir la litúrgia, cantar al cor...); és per això que ens ha estat el més fecund d'autores modernes, fins al punt que podem considerar-lo el gran centre de producció, de divulgació i de conservació de l'escriptura i la cultura femenines (Arenal/ Schlau 2010 [1a ed. 1989]). En l'òrbita d'aquesta producció per obediència, les religioses redacten també altres productes literaris espirituals de gènere variat (cròniques, llibres de memòria, elogis de difuntes...) i entre els quals destaca la producció de creació poètica.

En efecte, l'estat actual de la recerca sobre els usos escrits de dones de l'època moderna, basada en l'esmentada tasca constant de recuperació dels materials impresos i manuscrits que se n'han conservat, ens ha permés constatar que la poesia va ser una dels gèneres predilectes de les dones, conjuntament amb d'altres pràctiques d'escriptura. A través de la consulta dels catàlegs bibliogràfics antics $\mathrm{i}$ actuals, com també l'accés directe al textos, podem avançar algunes dades quantitatives que ens ajuden a perfilar, de manera provisional, un parnàs de poetesses (Palacios 2002, Herrero 2009, Zaragoza 2010) ${ }^{9}$ que al domini catalanoparlant documentem mínimament al segle XVI, es consolida especialment al XVII i es manté al llarg de la centúria del XVIII. Així doncs, amb la feina de recuperació de textos abordada fins ara tenim consignades un total de 270 autores dels territoris de parla catalana, ${ }^{10}$ de les quals més de la meitat, unes 150 dones van tenir alguna aportació poètica (conservada o no) en els diversos camps d'expressió: els certàmens poètics (la importància dels quals ja ha estat remarcada pel gran nombre de dones que hi van concórrer durant els segles XVI-XVIII); la moda de les poesies laudatòries proemials; la poesia seglar, entre la qual s'engloba també la publicada amb noms femenins en premsa periòdica valenciana i barcelonina a finals del s. XVIII (Aguilar 1981) i, especialment, la poesia conventual, sobre la qual ens centrem avui, després d'alguns primers intents d'acostament (Zaragoza 2011 i 2012).

Bona part d'aquestes composicions poètiques que les religioses van escriure intramurs -més enllà de la poesia circumstancial- ${ }^{11}$ foren destruïdes o romanen desaparegudes avui, i només ens són conegudes

8 Només com a mostra, Juan Gil Trullench Amella, col legial perpetu del Reial Col legi del Corpus Christi de València i promotor de la fundació del monestir de religioses dominiques de Vila-real (l'anomenat Corpus Christi) empresa per les religioses del convent de Santa Magdalena de València; en la dita fundació no només va dotar econòmicament la nova comunitat sinó que també li va cedir la seva biblioteca particular: «Y porque en comprar la casa, coadiuvar en formarla en convento, beneficiarle con ornamentos, calizes, adormos de reliquias y otras piezas para la iglesia, sacristia y altares; empleó más de seis mil ducados de plata y aun no bien satisfecha su piedad, hizo donación de toda su hazienda y libreria a dicho convento» (Rodriguez 1747: 261); citat a Sanhuesa (2004: 172).

9 Sobre el nou redreç que experimenta l'escriptura femenina al s. xvIII, pel que fa a la irrupció de temàtiques i d'espais de difusió seglars, més enllà de l'àmbit conventual, llegiu Bolufer (2007), entre d’altres treballs que li ha dedicat.

10 No se n’han conservat tots els textos, sinó que hi ha documentat aquest nombre d'autores.

11 Obviem en aquest treball de format limitat, les autores de poesia secular, amb una producció bastant diferent en relació a la que estudiem aquí (Romero-Díaz 2012); per tant, no prenem en consideració la gran quantitat religioses que també van aportar les seves composicions en els contextos de producció circumstancial (certàmens poètics i preliminars d'obra aliena) (Jung 2000 i Baranda 2005). Del mateix convent de Montsió, al qual pertany el manuscrit que ressenyem, trobem monges autores de poesia circumstancial: amb obra a preliminars (sor Gertrudis Llusàs i de Copons, sor Magina Valls i 


\section{Verònica Zaragoza. Escriure poesia al convent: entre la devoció i l'obediència. Primera aproximació a un manuscrit femení del segle XVIII}

per al lusions documentals, com és el cas de l'obra poètica de sor Gertrudis que acabem d'esmentar i d'altres casos que m'interessa reportar en l'apartat següent. I és que, al nostre parer és important que els tinguem en compte, atés que ens proporcionen una idea més nítida del que va suposar el fenomen de la poesia conventual femenina al panorama catalanoparlant. Pel que fa als textos poètics conservats, ens han arribat, generalment, com a complement de les Vides, Sermons i Cròniques oficials impreses (d'altres han quedat manuscrites) en el marc d'una estratègia de difusió proselitista que revertís en la comunitat i en l'orde. ${ }^{12}$

\section{El conreu literari conventual entre l'obediència i la devoció: història d'una destrucció}

Sobre aquest fenomen de la literatura conventual femenina per encàrrec (i especialment, el de l'autobiografia espiritual), alguns treballs de referència (Poutrin 1995, Haliczer 2002) han demostrat la complexa i rica en matisos vinculació entre aquestes religioses que escriuen i un determinat model de dona virtuosa (santes i beates, reconegudes o no), d'esperit il lustrat $\mathrm{i}$ beneficiària dels favors divins, del qual es pretén la promoció espiritual en plena època contrareformista inclinada per necessitat a «fabricar de sants». Segons aquest corrent historiogràfic actual, doncs, l'escriptura femenina a l'època moderna venia associada molts cops a la creació d'una determinada reputació de santedat, d'un determinat model femení de culte que reproduïa unes convencions, en resposta a uns models d'actuació i de religiositat proporcionats per l'abundant producció hagiogràfica consumida per la societat de l'època (Arellano/ Vitse coord. 2004, Bejarano 2012 i Garcia/ Llorca ed. 2012) i per les mateixes religioses, per a les quals la seva lectura suposava la base de la formació espiritual (Poutrin 2003). Explicat d'una altra manera: les religioses escriptores eren projectades com a ànimes espiritualment extraordinàries que, en funció d'unes motivacions pràctiques, doctrinals o proselitistes, escrivien per a les companyes de claustre i per als seus superiors, gairebé sempre sota l’imperatiu de l'obediència (Barbeito 2007: 62). Aquestes van acabar assumint un grau d'influència espiritual important, fins al punt que es considera:

$$
\begin{aligned}
& \text { [...] si bien se nutren en gran parte de maestros espirituales masculinos, sometidas esas } \\
& \text { lecturas a un proceso empírico de asimilación, a veces las adoctrinadas acaban erigiéndose en } \\
& \text { adoctrinadoras, en maestras aceptadas y seguidas por sus mismos confesores y directores de } \\
& \text { espíritu (Barbeito 2007: 66) }
\end{aligned}
$$

El llenguatge místic fou el canal més transitat de les religioses del període i els confegia cert protagonisme al món, malgrat l'enclaustrament que se'ls havia imposat arran dels decrets tridentins

una anònima) i com a participant d'un certamen (Rafaela Rey i Felig).

12 Com a mostra de la rellevància d'aquest model ideal de santedat femenina que repercuteix de manera positiva en el convent, en l'estudi sobre la història del monestir de clarisses de Santa Faç d'Alacant, una de les raons que addueix Cutillas per explicar l'auge de vocacions registrat al convent durant la centúria del dèsset fou la influència de sor Maria Bernarda Rico; malgrat que no va deixar obra escrita, sor Maria Bernarda fou una religiosa virtuosa de la comunitat, morta en olor de santedat, que va propiciar un focus d'espiritualitat més enllà dels murs conventuals i un ambient procliu per incoar el seu procés de beatificació (1996: 68). 
(1545-1563). ${ }^{13}$ Fou a través d'aquest discurs místic que les dones van adquirir una autoritat que de cap de les maneres podien assolir a extramurs (Sánchez 1988: 341-351). Això sí: sempre aixecant la sospita d'aquells mateixos que les instaven a escriure. Com ja s'ha vingut demostrant en els darrers anys, la religiosa o beata de l'època moderna no només va deixar escrites les seves vivències espirituals per construir un determinat model de dona il luminada, amb el propòsit de despertar la devoció conventual, la pietat popular i la meravella en el poble, sinó que aquells escrits també s'havien generat en el context de control inquisitorial, en el procés de desemmascarament i de silenciament d'aquella «desordenada devoció» de les anomenades simuladores de santedat, il luses... (Giordano 2007: 77) allunyades de l'ortodòxia (Guilhem 1981, Rhodes 2000). A l'àmbit catalanoparlant, una d'aquestes místiques acusades d'heterodòxia, de la qual ens han arribat els sus escrits fou la terciària dominicana Rosa de Santo Domingo (Poutrin 1995: 310). Amb el nom de Maria Antònia Ortolà, va nàixer a Senija (Marina Alta) cap al 1695 i a partir de 1717, començà a ser processada pel Sant Ofici, acusada de fingir revelacions. Després d'un segon procés incoat el 1724, va ser declarada culpable d'impostora i condemnada a reclusió perpètua, que va esdevenir un dels càstigs més freqüents per a aquestes declarades falses místiques relegades per sempre més al silenci. Segons Poutrin, en la secció de la Inquisició de l'Arxiu Històric Nacional, es conserva una extensa relació de la vida espiritual autògrafa d'aquesta beata, ${ }^{14}$ així com un recull dels favors rebuts ${ }^{15}$ i, dues còpies del segle XVIII integrades en el lligall intitulat: «Papeles originales tocantes al espíritu de María Antonia Hortola, alias la Hermana Rosa de Santo Domingo. Son copia de los originales». ${ }^{16}$ L'interés d'aquesta autora en aquest treball que avui ens ocupa radica en el fet que dins d'aquest material inquisitorial de caire autobiogràfic també hi trobem unes Coplas que compuso al amor divino, en castellà.

Com veiem, malgrat que els usos autobiogràfics de les nostres autores han acaparat l'atenció de la crítica, és interessant remarcar que gran part d'elles també es van dedicar (en major o menor mesura) a l'acte de creació poètica (fortament relacionat, d'altra banda, amb el cant, com a cim de l'expressió del sentiment devot (Zaragoza 2012). ${ }^{17}$ Més enllà de l'experiència espiritual narrada en les Vides, les rimes

13 La implantació de la clausura es va reglamentar en la sessió XXV del Conclili de Trento, fou ratificada per les bules papals de Piu V -Circa Pastoralis (1566) i Decori et honestitati (1570) i va afavorir un nou model de vida contemplativa, però no fou efectiva en aquests segles, tal com s’ha anat demostrant (Hernández 2002 i Zaragoza 2011).

14 AHN. Proceso de fe, Inquisició de València, 1717-1726, Lligall 532, peça 3.

15 AHN. Proceso de fe, Inquisició de València, 1717-1726, Lligall 532, peça 4.

16 AHN. Proceso de fe, Inquisició de València, 1717-1726, Inq. Lligall 532, peça 1.

17 En els darrers anys s'han publicat interessants treballs que revelen una rica activitat musical en els convents femenins de l'època; vegeu entre d'altres, Olarte (1993), Aguirre (2004), Sanhuesa (2004), Sánchez (2011). Malgrat que no està centrat només en l'àmbit conventual, també resulta valuós revisar el treball de Mazuela-Anguita (2012), tesi recentment apareguda que versa sobre la cultura musical femenina a la Península Ibèrica durant el període 1492-1626, i que ofereix una nòmina de dones músiques o posseïdores de llibres musicals, algunes de les quals també tenen obra escrita, com ara la poetessa i música valenciana Tecla de Borja (II: 386) o Juliana Morell (II: 392). 


\title{
Verònica Zaragoza. Escriure poesia al convent: entre la devoció i l'obediència. Primera
} aproximació a un manuscrit femení del segle XVIII

espirituals també permetien a aquestes dones expressar líricament la seva devoció, adoctrinar en la fe les companyes $i$ instar-les al compliment de les virtuts, alegrar l'ambient conventual, molts cops hostil i marcat per un estil de vida disciplinada, etc. (Barnada 2005: 92).

En relació a aquestes composicions que incloem en la pràctica d'escriptura per obediència al confessor, compartim la idea proposada per l'estudiosa E. Graziosi:

\begin{abstract}
Insieme alla devozione e al desiderio di fama mondana, l'obbedienza al confessore poteve essere certamente per le monache motivazione importante alla scrittura. Importante ma non sufficiente a giustificare l'uso della rima che è prova di abilità e non può essere imposta come practica di ascesi spirituale. Bisogna dunque pensare che le monache poetesse che scrivevano su ordine del direttore spirituale, ritenessero di poter dire in rima cose che non erano altrimenti compiutamente esprimibile o che avevano sul lettore effeti altrimenti inttangibili (1996: 314).
\end{abstract}

Així doncs, hem de pensar que rere l'acte d'escriptura poètica conventual no hi havia només el desig d'obeir al manament del confessor sinó també la necessitat expressiva i l'habilitat de moltes religioses contemplatives per exterioritzar, amb menor o major fortuna, la seva experiència mística i les seves comunicacions quotidianes i individuals amb l'espós Jesucrist. Encara que en menor proporció, les religioses també utilitzaven la poesia per expressar devoció a la Mare de Déu, tal com demostra l'obra desapareguda de sor Maria Isabel Francesch i Escurpí (Riudecanyes, 1715-Barcelona, 1788). Segons la seva Vida impresa, aquesta religiosa del convent de Nostra Senyora dels Àngels i Peu de la Creu de Barcelona va escriure un quadern amb la seves experiències espirituals, així com cobles i poemes de temàtica devota vers la Mare de Déu a la qual «se la expresaba freqüentemente con afectuosas y enérgicas coplas y otros poemas, en que encarecía sus grandezas y virtudes y su tierno amor con los pecadores» (Morat 1789: 174). Malauradament, mai no sabrem en exactitud què va escriure aquesta religiosa, ja que l'obligada modèstia i la humilitat esperada, la van induir a cremar-ho tot abans de morir, com s'esdevingué amb tantes d'altres, de la qual cosa es lamenta el compilador de la seva Vida, que considerava que:

Estas producciones ingeniosas hubieran sido el monumento más incontrastable del ilustrado espíritu de una muger que nunca aprendió en otra escuela que en la de la oración y penitencia. Pero perecieron en las aras de la humildad de Isabel, que las arrojó al fuego con los demás papeles en que se hallaban escritos los favores más señalados que había recibido de su esposo y de su madre amabilísima; y con otros en que desentrañaba lo más profundo de los misterios de nuestra santa religión. Lo único que se sabe de ellos es lo que leyó una monja, muy confidenta de nuestra heroína, llamada sor María Catalina Burrull. Habiendo entrado en su celda a la sazón que no estaba Isabel y reparando sobre la mesa un quaderno en que escribía su vida privada por orden de su confesor, leyó [...] (Morat 1789: 174).

Notem com, malgrat que Morat considera la religiosa com un «ilustrado espíritu», incideix en els tòpics de manca de cultura per part de l'autora, a fi de justificar l'obra, tot situant-la en l'àmbit de la fe: «nunca aprendió en otra escuela que en la de la oración y penitencia», tal com també havia fet el biògraf de l'esmentada sor Gertrudis. 


\title{
Verònica Zaragoza. Escriure poesia al convent: entre la devoció i l'obediència. Primera aproximació a un manuscrit femení del segle XVIII
}

Una altra autora que també ens hauria deixat obra poètica acompanyada de materials autobiogràfics espirituals escrits del seu puny fou sor Maria de Santa Clara (Russafa, 1737-1805), coneguda només per les referències que trobem al Sermó imprés amb motiu de les seves exèquies. Segons hi consta, una còpia dels papers de la religiosa estava en possessió del pare Joaquim Llansol, que els va fer servir de font per escriure el citat Sermó. Sobre aquesta clarissa del convent de la Nostra Senyora dels Àngels de Russafa, extramurs de València i priora de la comunitat, s'hi explica que quan el confessor li ordenà que escrivís un quadern amb les seves experiències, sor Maria, sense tenir nocions d'escriptura ni de la llengua castellana, n’aprengué amb un abecedari manuscrit i que:

La primera carta que escribió a su director, dándole cuenta de su interior fue en verso, sin haber visto jamás verso ni saber lo que era poesía. Continuó en escribir a sus directores, pero siempre con la prevención que habían de quemar o rasgar las cartas. Y a no estar en esta persuasión, le hubiera servido el escribir de un cruel martirio. Cuando escribía lo hacía a oscuras muchas veces; otras, fuera de sus sentidos, y cuando volvía en sí, hallaba escrito aquello mismo que le había pasado en la elevación del espíritu, aunque con expresión y modo muy inferior a la elevación de las inteligencias divinas que se le habían infundido a su espíritu en el exceso mental. Algunas veces, cuando escribía no era libre en escribir lo que pensaba sino que escribía lo que el Señor quería, impelida de su divino espíritu; ni el modo que pensaba. Porque unas veces quería escribir en prosa y salía en verso; otras, pensando escribir un asunto, se veía impelida a dejar correr la pluma a otro que el Señor quería (Llansol 1805: 4-5). ${ }^{18}$

En relació a les motivacions de l'obra d'aquesta religiosa, malgrat que és una descripció llarga, és interessant recollir les paraules de l'autor del Sermó, que explica el caire d'escriptura i les motivacions, així com algunes dades relacionades amb la formació de l'autora, sempre incidint en la seva incultura (i fins $i$ tot, en el desconeixement de la llengua castellana) i en la capacitat de rebre coneixements per ciència infusa, segons els tòpics de l'època:

\begin{abstract}
Fin y motivos porque escribió, y modo de escribir: Ni sabía escribir, ni leer letra de mano, ni tampoco hablar el castellano. Le parecía que en el confesionario no se explicaba bien; que el confesor no la entendía y que por consiguiente no la podría dirigir bien: que si supiese escribir, lo podría conseguir todo, el explicarse a su satisfacción, y la mejor dirección de espíritu. Manifestó su pensamiento al confesor y éste sin duda inspirado por Dios, la mandó que escribiera. Escusóse diciendo que no sabía ni leer ni escribir letra de mano, ni aun la había visto jamás. La mandó el confesor que pidiera a una religiosa un abecedario manuscrito y que probase a escribir. La primera vez que volvió a confesarla, le repitió el precepto que desde entonces le había de dar cuenta de su interior por escrito. $\mathrm{Y}$ aunque halló mucha resistencia para cumplirlo, nacida de su profundísima humildad, se ofreció a obedecer bajo las condiciones humildes, que el confesor había de rasgar las cartas después de leídas y enterado de ellas para su dirección, y que no había de poner su firma, y otras, muy propias de una sólida, verdadera y profunda humildad. Luego que el confesor le intimó el precepto, se puso a escribir y continuó hasta que los confesores le suspendieron el precepto, porque no podía cumplirlo buenamente por sus muchos achaques (Llansol 1805: 3-4).
\end{abstract}

\footnotetext{
18 Reprodueix un fragment dels escrits de la religiosa (Llansol 1805: 123 i 132), segons ell «del tercer quaderno», cosa que ens indica que sor Maria de Santa Clara hauria deixat almenys tres quaderns escrits. 


\title{
Verònica Zaragoza. Escriure poesia al convent: entre la devoció i l'obediència. Primera aproximació a un manuscrit femení del segle XVIII
}

Al capdavall, pel que fa a la personalitat i el carisma d'aquesta religiosa i de la producció poètica resultant, traçades al Sermó, es corresponen amb els casos de les místiques del període: beneficiàries dels favors rebuts per Déu, necessiten expressar els seus sentiments a través de la lírica mística de contingut amorós. Així, a continuació se'ns apunta vers una poesia molt influenciada pel Càntic dels Càntics (possiblement, tocada per l'influx directe del carmelità Juan de la Cruz) en què l'ànima té col loquis amorosos amb el Senyor, el seu Espós:

\begin{abstract}
Semejantes a éstas y aún más expresivas son las locuciones interiores que tenía con el Señor y que escribió de orden de su confesor y por mandato del Señor, muchas veces intimado, con el fin de que perdiese el excesivo temor que tenía de ser engañada del demonio. Porque aunque en el acto mismo de estas hablas interiores tenía íntima certeza y seguridad de que era el Señor quien la hablava, y la infundía las respuestas y el estilo poético; pero descendiendo después su alma a un estado natural, le penetraban estos temores para exercicio de su profunda humildad y heroica obediencia (Llansol 1805: 91-93).
\end{abstract}

Fet i fet, veiem en els Sermons o Vides impreses de les autores que hem anat revisant, els biògrafs repeteixen els mateixos tòpics en relació als usos poètics de les religioses: aquestes no tenien habilitats per escriure poesia sinó que les aprenien de manera infusa. Amb això, s'intentava remarcar que es tractava d'una poesia de caire intimista, impregnada de fervorosos afectes més que no pas d'artificis literaris, tot relacionant l'acte de creació poètica al convent amb una determinada santedat (Morujão 1996). Sobre la pervivència d'aquest model líric místic influït pels grans mestres (Teresa de Jesús, Juan de la Cruz...) conreat als convents femenins encara al segle XVIII (al qual pertanyen les autores que hem tractat $\mathrm{i}$ també el manuscrit que tot seguit revisem), l'estudiós Palacios explica el fenomen citant les paraules expressades per Leopoldo Augusto de Cueto, el 1889:

\footnotetext{
Como contraste y afrenta del carácter material y rastrero que había tomado la poesía, se presentaban de cuando en cuando ejemplos de la mística poética que con tanta vehemencia como esplendor habían cultivado san Juan de la Cruz y la incomparable madre santa Teresa de Jesús. En imaginaciones femeniles prendía fácilmente aquel sagrado fuego, que, si bien envuelto en formas metafísicas, servía a un tiempo de pábulo y desahogo a los arranques de amor divino que abrasaba su alma. Aunque ya desmayada y tibia, todavía llegaba a encenderse aquella luz ardiente en la vida contemplativa y mística del claustro (Palacios 2002: 174).
}

Com hem pogut constatar en els apartats anteriors, la revisió exhaustiva dels textos impresos escrits per homes propers a les religioses (a partir dels papers d'aquestes, després d'exercir-hi la censura corresponent (Peña 1999 i Weber 2005a), ens permetrà augmentar la llista de religioses que van trobar en la poesia un complement ideal per expressar la seva espiritualitat i el seu amor fervent a Déu. Sens dubte, davant d'aquesta gran quantitat d'obra que ens consta desapareguda, qualsevol indici sobre usos poètics se'ns planteja com a dada fonamental a tenir present i en aquest sentit, tota troballa manuscrita com la que pretenem analitzar a continuació esdevé un «còmplice de la memòria» ideal (Frenk 1993) indispensable per a la reconstitució del panorama poètic femení modern. 
Verònica Zaragoza. Escriure poesia al convent: entre la devoció i l'obediència. Primera aproximació a un manuscrit femení del segle XVIII

\section{Primer acostament al manuscrit i a l'autora}

El quadern que avui analitzem, amb el títol de Coblas és obra de sor Eufràsia o Eulària Teixidor i Pujades, ${ }^{19}$ tal com queda registrat al llom del manuscrit (Sor E. Teixidor, OP (Montsió) Coblas, 1767) i en el darrer full, gràcies a una anotació posterior que hi féu el confessor. Fou religiosa del monestir de Santa Maria de Montsió, fundat el 1347 a Barcelona i actualment emplaçat a Esplugues de Llobregat, després de diversos trasllats (Paulí 1952 i Hernández 1997 i 2002). D’aquesta autora no hem pogut esbrinar gaire informació però sí que podem ubicar-la mínimament en unes coordenades temporals i espacials. Així, gràcies a la documentació a què hem pogut accedir a l'arxiu de la comunitat de la religiosa, Eulària Teixidor va nàixer el 1712 a Barcelona, ${ }^{20}$ filla del notari Ramon Teixidor «burgés honrat de la vila de Perpiñá» i d'Alemanda Pujades (aleshores difunta). Va entrar al convent com a monja corista el 22 d'abril de $1737,{ }^{21}$ a vint-i-cinc anys, després d'aportarhi les 800 lliures corresponents de dot, i hi va professar al voltant de 1740, després d'un any de noviciat. La religiosa va romandre la resta dels seus dies al convent, on va alternar la seva dedicació literària amb el càrrec de prioressa, durant els anys 1752-1755 i reelegida el 1765 fins a la seva mort el 1767 (la data que consta al llom del manuscrit). ${ }^{22}$

Abans de passar a descriure el volum és interessar reflexionar sobre una qüestió, relacionada amb la seva procedència: actualment es troba al monestir de Sant Benet de Montserrat, pertanyent al fons

\footnotetext{
19 Cal advertir que tant en la documentació d'arxiu consultada com en la signatura de la religiosa present en alguns documents, l'autora hi consta amb el nom de sor Eulària. El nom de sor Eufràsia present al llom del llibre, ens arriba només a través de la nota escrita pel confessor, que l'esmenta així: «La monja que escrivió todas las coblas de este libro y las compuso del modo que ella avisa en su prólogo fue la R.M.V. Eufrasia Teixidor, que murió siendo priora del convento de Montesión, orden de predicadores de Barcelona, a la una de la mañana del día mes de julio de 1767, la qual hubo una enfermedad muy penosa y prolongada y en ella fue assombro de resignación y paciencia a todas las monjas; y que su muerte para todas de grande constancia y exemplo por dexarles evidentes señas de ser su muerte la más graciosa a los ojos de Dios [...]» (f. 248). Més enllà que és tractés d'una simple confusió, és plausible considerar que el confessor pretengués imprimir un cert reflex de santedat en la nostra mística, vinculant-la amb el nom d'una santa coneguda (santa Eufràsia), atribuït també a una religiosa virtuosa de la mateixa comunitat de Montsió. Aquesta, una reconeguda mística i visionària, d'una gran autoritat espiritual, fou sor Eufrasina Toralla morta el 1466 que en paraules de M. Soledad Hernández, va encarnar «el modelo de santidad femenina que se sustenta en la catarsis penitencial y donde la mujer podia adquirir una potente gracia carismática a traves de la "ratio» dolorosa y gestual imitativa de la Pasion de Cristo, encarnando la humanidad “maternal» de Dios» (1997: 32). En definitiva, considerem que el nom d'Eufràsia és tracta d'una atribució del confessor, i que l'autora s'anomena Eulària, nom religiós que presumptament coincideix amb el del bateig ja que en aquesta comunitat les religioses no solien canviar el nom seglar, per un d'altre de religiós com m’informa l'estudiosa M. M. Gras. Per aquests motius, m’hi referisc com a Eulària, a falta de noves dades.
}

20 Arxiu de Dominiques de Montsió (ADM), Profesiones 1657 a 1834, [f. 34].

21 ADM. Llibre de professions, 1646-1888, f. 21r

22 ADM. Llibre d’òbits, f. 36. La data de defunció també consta al darrer full del manuscrit que estudiem.

SCRIPTA, Revista internacional de literatura i cultura medieval i moderna, núm. 1 / juny 2013 / pp. 333-361 ISSN: 2340-4841 · doi:10.7203/SCRIPTA.1.2590 
de santa Clara de Barcelona. ${ }^{23}$ Aquest origen inesperat del manuscrit -malgrat que encara no estem en condicions d'apuntar cap hipòtesi sobre la seva circulació- ens permet plantejar-nos una sèrie de qüestions: hi ha la creença massa generalitzada que els decrets tridentins van relegar les religioses a l'ostracisme i a la clausura conventual absoluta, allunyades del món material, i per tant, de les pulsions esteticoliteràries imperants del moment. També es considera que els escrits que ens han arribat de les religioses de l'època moderna, van comptar amb una nul la circulació, adreçades només a les seves companyes de professió i a l'ús que en, darrera instància, en volguessen fer les instàncies eclesiàstiques en morir l'autora (impressió de la Vida o Sermons, cròniques oficials de l'orde o convent...). Ara bé, el fet que aquest manuscrit traspassés els murs claustrals on originàriament fou creat, aparentment per a ser consumit intramurs, $i$ hagués aparegut al convent de les aleshores clarisses barcelonines (Jornet 2007), ens demostra novament la permeabilitat dels límits claustrals (Zaragoza 2011). D’altra banda, aquesta troballa ens projecta el món conventual femení com un espai idoni per a la circulació, intercanvi i consum d'una producció poètica femenina (i també masculina) que sovint era copiada i que no només circulava de forma manuscrita a dins del convent sinó que era intercanviada fins i tot entre comunitats d'ordres diferents (Barbeito 2007: 48), com és el cas que avui ens ocupa. ${ }^{24}$ En definitiva, no deixa de ser sorprenent descobrir com aquest autògraf que en principi havia de ser d'ús personal de sor Eulària (i a tot estirar de la seva comunitat) esdevingué lectura, i, per tant, focus d'influència, d'una comunitat de religioses d'un orde completament diferent $\mathrm{i}$ amb tradicions divergents.

Enquadernat en pergamí, el llibre poètic conté 250 fulls, de paper $(1 \mathrm{f}$. de guarda $+1 \mathrm{p} .+248$ ff; amb foliació moderna en llapis). Els fulls fan 200 x $155 \mathrm{~mm}$, escrits a una sola columna. El volum està escrit íntegrament en castellà i està conformat per tres seccions, escrites per dues mans: en la primera pàgina trobem l'obligat pròleg, amb referències a les circumstàncies i la motivació d'escriptura de l'obra. Cal apuntar la importància d'aquesta secció en una obra d'autoria femenina, per tal com, impregnada de la retòrica de la captatio benevolentiae havia de servir a la dona que escrivia per autoritzar-se com a veu emissora davant dels seus lectors i legitimar aquella obra: "Como estructura retórica se coloca al inicio de la dispositio de las partes de un discurso y como el exordio cumple una función introductoria de preparación del auditorio» (Luna 1993: 597). A aquest breu apartat, hi segueix la transcripció de 53 composicions, de caràcter eminentment devot, com tot seguit veurem. Pel que fa a la definició de cobla (catalanisme de copla), el Diccionari Català-ValenciàBalear recull el significat d' «Estrofa; conjunt d'alguns versos, que sol constituir la lletra d'una cançó popular» (s.v. Cobla). Per la seva part, Díaz Rengifo considerava al «Capítulo XXI. De la consonancia

23 ASBM, SACB, Producció literària. Núm. 662. Cal advertir que Sant Benet de Montserrat és una institució monàstica femenina de creació moderna (1952), com a conseqüència de la fusió de dues comunitats preexistents: el monestir de clarisses de Sant Antoni i Santa Clara de Barcelona (1233/36-1952) i el monestir de benedictines de Sant Benet de Mataró (1881-1952). L'actual monestir, doncs, acull els fons històrics d'ambdues comunitats (MSCB) i (MBM), així com la documentació actual generada per la comunitat monàstica vigent (MSBM) (Jornet 2007).

24 Entre les pàgines del volum trobem un full solt que conté un sonet, anònim, que tal com clama el títol es tracta d'una traducció copiada amb una bella cal ligrafia i una caplletra de color vermell. Es refereixen a aquest llegat manuscrit que circulava en l’àmbit conventual femení Cátedra,/ Rojo (2004: 115). 


\section{Verònica Zaragoza. Escriure poesia al convent: entre la devoció i l'obediència. Primera aproximació a un manuscrit femení del segle XVIII}

de las coplas», de la seva Arte poética española... que:

Copla se dixo de copula, vocablo latino que quiere decir unión y junta porque no es otra cosa copla sino junta de versos en particular [...] En la copla hay dos cosas: cierto número de versos y cierta consonancia entre los fines de ellos y, según la variedad de estas dos cosas, se diferencian y varían las coplas» ([1759]: 29).

Per tant, ens trobaríem davant composicions en principi per a ser cantades, agrupades en estrofes de versos heptasil làbics, encara que també hi trobem algunes dècimes. Pel que fa al llenguatge emprat, és senzill, planer i afectuós, amb la presència constant del jo poètic, en 1a persona, davant un interlocutor que generalment és Déu o d'altres destinataris intratextuals divins (Mare de Déu, Teresa de Jesús...).

Les dues parts que conformen el gruix del volum (pròleg i composicions) són autògrafes de la religiosa, ja que després d'analitzar paleogràficament el contingut, hem advertit que el tipus de lletra coincideix amb la de la signatura de sor Eulària, consignada en documents administratius de l'arxiu. Finalment, tanca el quadern una nota del confessor, que proporciona les dades de l'autora, ja que la religiosa no havia signat el volum tal com feien d'altres autores que esperaven, amb l'anonimat, no rebre acusacions de supèrbia i vanitat per aquella obra. El confessor també hi transcriu una dècima, en castellà, que sor Eulària li havia adreçat en una de les seves cartes (de moment il localitzables però que ens apunten vers una relació epistolar regular, com tantes d'altres religioses van fer amb els seus confessors), un mes abans de morir, i que hi és copiada «para gloria de Dios» (Coblas, 248).

Com ja hem esmentat, el manuscrit pertany estrictament a l'àmbit de la realització devota; ${ }^{25}$ és interessant analitzar-ne el pròleg atés que apunta vers unes coordenades que mereixen ser explicades en relació al fenomen de l'escriptura femenina conventual i, especialment, la que obeeix a la llicència del confessor. Això ens permetrà emmarcar l'obra en el seu context de creació, albirar les motivacions i copsar el to místic emprat i la predilecció per uns determinats temes. Analitzem-ho:

Coblas que á escrito una religiosa ignorante, sin letras ni arte no quando ella quiere sino quando Dios se lo da, que las más vezes es en la oración, en donde siente un movimiento en su interior que le parese no puede quietarse asta aberlas escrito. Otras vezes se lo manda su confesor quando ella menos piensa y aunque le parese imposible entonces dezir cosa, no se atreve a replicar, confiando que aquel Sr. que le movió a él para mandárselo le dará grasia a ella por obedezer; y así susede que todas se asen con muy poco trabajo, que si fuese nesesario discurrir mucho en ninguna manera lo aría pues su fin sólo es ensender la voluntad en el amor

25 Del mateix to i característiques, s'ha conservat l'obra poètica manuscrita de la religiosa toledana sor María de Santa Isabel (amb pseudònim Marcia Belisarda), que malgrat que fou preparada per a ser publicada, finalment s'ha conservat inèdita a la Biblioteca Nacional d'Espanya; recentment, aquest autògraf ha estat objecte d'estudi (Cerezo 2012). 


\title{
Verònica Zaragoza. Escriure poesia al convent: entre la devoció i l'obediència. Primera aproximació a un manuscrit femení del segle XVIII
}

\begin{abstract}
de Dios y traer el pensamiento ocupado en su dulze Esposo. Y así las más, las á conpuestas ocupada con sus obediencias, en espesial las de la Sagrada Pasión y las miditaciones del Padre Nuestro, que en esa ocación eran artas sus ocupasiones y muchos los disgustos; y por ese motivo y no tener ella arte an de ir con muchas faltas, pero no piensa que lo aya de ver sino su confesor, a quien lo remite por obedezer lo mandado. Viva Jesús (Coblas, p.1)
\end{abstract}

En aquest valuós prolegomen, sor Eulària hi plasma els tòpics als quals ens té acostumats la immensa majoria d'escriptores de l'època per posicionar-s'hi davant l'acte de creació literària amb «afectada modèstia». Es tractava d'una manera convenient i gairebé obligada d'autoritzar la paraula femenina, a fi de curar-se de la possible censura i acusació de supèrbia. Tal com hi llegim, sor Eulària parteix d'una actitud d'humilitat, tot recorrent al tòpic de l'autora illetrada, ignorant que no busca fer art ni literatura, perquè no en sap. També hi és present la idea de subjecció al confessor i a l'Església: davant l'obligació d'escriure que li ve imposada pel confessor (que actua, alhora, en nom diví), la religiosa sols aconsegueix fer-ho gràcies a la gràcia de Déu, l'agent actiu que no només hi intercedeix com a «musa inspiradora» sinó que allò que escriu, ho rep al dictat diví. Al capdavall, l'autora busca assolir una posició d'autoritat, tot situant-se davant la pròpia obra com a interlocutora directa de Déu, com a intermediària de la paraula divina. A més a més, el pròleg també aborda la doble motivació de l'obra:

D’una banda, la poderosa necessitat expressiva pròpia de la vivència mística, que empeny a escriure poesia en la lloança divina, tal com ja havia manifestat la mestra Teresa de Jesús en relació a la seva obra poètica:

\footnotetext{
¡Oh, válame Dios cuál está un alma cuando está ansí! Toda ella querría que fuese lenguas para alabar a el Señor; dice mil desatinos santos, atinando siempre a contentar a quien la tiene ansí. Yo sé persona que, con no ser poeta, que le acaecía hacer de presto coplas muy sentidas declarando su pena bien, no hechas de su entendimiento, sino que, para más gozar la gloria que tan sabrosa pena le daba, se quejaba de ella a su Dios (Vida, 16, \4).
}

D'altra banda, el pròleg també emmarca les composicions en la fórmula de l'escriptura per obediència, que trobem també explicitada en algunes rúbriques del quadern, com ara: «Coblas que escrive una $\mathrm{r}^{s a}$ a quien á mandado su confesor que le explicase en unos versos los efectos que abia sentido en los diez dias de sus exercicios espirituales» (ff. 18-31), «Coblas a San Agustin conpuestas en el dia de su festividad, por aberlo asi mandado a una alma su confesor» (ff. 103-107), «Coblas que ase una alma en tiempo de sequedad, y obscuridad de entendimien[...], por aberselo mandado su confesor despues de mucho tiempo que se lo tenia privado» (ff. 114-120), «Coblas que ase una re $\mathrm{ra}^{\mathrm{sa}}$ a su patrona $\mathrm{S}^{\text {ta }}$ Teresa de Jesus, por orden de su confesor en ocasion que le paresia inposible dezir cosa y le mando cotejase la distansia que abia de su vida a la de la Santa» (ff. 128131), «Coblas que ase una alma el dia de la flecha de $S^{\text {ta }}$ Teresa, que abiendo pedido licensia a su Confesor por comulgar aquel dia se la consedio con condision que conpusiese unas coblas en accion de grasias» (ff. 139-144). Així doncs, segons especifica l'autora al pròleg, les peces són fetes 
Verònica Zaragoza. Escriure poesia al convent: entre la devoció i l’obediència. Primera aproximació a un manuscrit femení del segle XVIII

«con sus obediencias» i semblen formar part dels exercicis espirituals estipulats pel seu confessor, basats en el recolliment i l'espiritualitat més contemplativa. En l'esmentada nota prologal, Eulària hi remarca especialment les composicions referides a la contemplació de la imatge de Jesucrist sofrent en la Passió, que en el quadern n’hem localitzat tres: «Coblas de quando el Sr. llevó la Cruz por la Calle de Amargura» (ff. 14-17), «Coblas de la oracion del huerto» (ff. 90-93) i «Coblas de una alma esposa de Jesu Cristo que dezea aconpañarle en su dolorosa Pasion asta dar la vida con el en el calvario y quedar sepultada en su sagrado costado» (ff. 154-197), un extensíssim poema de 1.072 versos en què la religiosa reviu les escenes del Via Crucis com si ella fos un altre personatge bíblic més present en els esdeveniments. Segons expressa la religiosa, també responen a l'obediència les anomenades «miditaciones del Padre Nuestro», amb què es refereix a les set composicions, una per a cada dia de la setmana, agrupades al quadern sota el títol: Meditaciones sobre la oracon [sic] del Padre Nuestro, repartidas por los siete dias de la semana, benerando a Dios cada dia con un nuebo titulo (ff. 32-51). Són les següents: «Lunes. En este dia contempla el alma a Dios como a su Padre y digale, Padre nuestro que estas en los Cielos, bendito sea tu nonbre» (ff. 32-34), «Martes. En este dia considere el alma a Dios como a su Rey y digale de corazon, Rey Nues. venga a nosostros tu $S^{t o}$ Reyno» (ff. 34-36), «Miercoles. En este dia se venera Dios como esposo y asi diga alma; vuestra voluntad se aga en la tierra como al Cielo» (ff. 36-38), «Jueves. Meditacion para que el alma despierta el amor considerando a Jesús como a Pastor, y asi dira el Pan nuestro de cada dia danosle yo» (ff. 39-41), «Viernes. En este dia se á de considerar que Jesus es Redemptor de nuestras almas y dezirle con afesto, Redentor mio perdonanos nuestras culpas, como perdonamos nu deudas» (ff. 41-44), «Sabado. En este dia se considera Jesus medico de nuestras almas; $\mathrm{y}$ asi diga con mucha confiansa, no nos dejes caer en tentacion» (ff. 44-48) $\mathrm{i}$ «Domingo. En este dia se venera a Dios como a juez; y asi diga el alma con rendimiento: Jues mio, librame de todo mal. Estas coblas se hisieron en tiempo del terramoto de Portugal, quando se vio llorar la imagen de la Virgen, del Rosario de la villa de la Guardia» (ff. 48-51).

Aquesta darrera rúbrica, amb marcat to informatiu, al ludeix a dots fets històrics d'especial transcendència per al món catòlic de l'època, esdevinguts ambdós l'1 de novembre de 1755: d'una banda, el famós terratrèmol de Lisboa, un dels més devastadors de la història, que va arribar a destruir gairebé per complet la ciutat i que va sacsejar tota la Península; d'altra, el fet miraculós esdevingut a Guàrdia, en què es va veure la Mare de Déu del Rosari plorar sang i suor. Es conserva impresa una còpia d'una carta enviada el dia 26 de novembre del mateix any, pel pare Vicente Collados, prior del convent de dominics de Jaén a Narcís de Guindos, prior del convent de Santa Cruz de Granada, en què li informava sobre l'esmentat prodigi:

[...] no me hallo con libertad para silenciar el sucesso que oy tiene pendiente la expectación de este reyno, desseando todos saber de un prodigio, como el de llorar y dudar una imagen de Nuestra Señora del Rosario, quando estaba llorando sangre toda nuestra Península por el nunca visto terremoto del día de Todos los Santos» (1755: 1).

Gràcies a la referència d'aquests fets que van commoure tant la consciència de la religiosa fins 


\section{Verònica Zaragoza. Escriure poesia al convent: entre la devoció i l'obediència. Primera aproximació a un manuscrit femení del segle XVIII}

al punt de considerar convenient de fer-ne esment en les seves composicions devotes, podem esbrinar la data d'escriptura d'aquestes peces: als volts de novembre de 1755, el mateix any en què sor Eulària va deixar de ser priora (després seria reelegida al cap de deu anys). Tot i que no ens ha estat possible esbrinar la data exacta del nomenament i del cessament en el seu càrrec més enllà de l'any, podríem conjecturar que el moment en què escriu algunes composicions (almenys aquelles meditacions), coincideix encara amb el seu govern a la comunitat. Això explicaria la remissió a la problemàtica que li suposa l'escriptura, quan Eulària al pròleg explica que «en esa ocación eran artas sus ocupasiones y muchos los disgustos» (Coblas, p. 1).

Per comprendre l'abast de les paraules de sor Eulària és important considerar el paper actiu de les priores en la gestió i l'organització de les comunitats conventuals del període, així com l'autoritat i el poder que hi van assolir. L'abast del poder i la responsabilitat de les priores dominiques ha estat estudiat recentment per Àngela Atienza, que en remarca la superioritat i la preeminència interna d'aquestes dones, encarregades tant del control de la vida quotidiana conventual com de la gestió econòmica. A més a més, la figura de la priora, màxima autoritat de les comunitats religioses femenines, no sols havia de ser-hi la garant de l'ordre i la disciplina conventual, sinó que s'exigia que fos dipositària d'unes virtuts que s'esperaven en ella, tal com recollia la Regla de nro. gran padre San Augustín, doctor de la iglesia y constituciones o manual de las monjas del orden de sr. sto. Domingo de Guzmán, que en esta reimpressión costea la provincia de Andalucía, del orden de predicadores, este año de 1765 (Sevilla, Imp. de F. Sanchez reciente, [1765]), coetània, per tant, al govern de sor Eulària:

\footnotetext{
Debe la madre priora, como cabeza y prelada de las demás religiosas, ser espejo de toda santidad, y virtud, y muy zelosa de toda la observancia regular, de tal manera, que sea la primera en todas las cosas de virtud y santidad, como en el exercicio de la Oración, frecuencia de los Santos Sacramentos, de Penitencia, y Comunión, assistencia al Coro y Refitorio, y casa de labor, para que con su exemplo, mas que con palabras, enseñe y exhorte a las demás religiosas, que hagan lo mismo (Atienza 2013: 58).
}

Precisament és aquesta la clau interpretativa d'una composició interessant, que comença el quadern, l'esmentada «Sentimientos de una alma q. dezeando vivir en soledad le trae ocupada la obediencia y se aflije por las muchas faltas que comete con el trato de las criaturas» (ff. 1-4), amb l'incipit: ${ }^{26}$

\footnotetext{
26 La recerca de la soledat conventual és un anhel recurrent en l'obra de les religioses de l'època. L'autora sor Marcela de san Félix (Toledo, 1605- Madrid, 1687), dramaturga i poetessa cèlebre, filla de l'escriptor Lope de Vega, també va dedicar dues composicions a aquest tema de la soledat conventual. L'un, amb la rúbrica «Otro romance a una soledad», on la religiosa manifesta el desig de pau conventual o intimitat necessària que per a l'ànima amorosa només pot venir a través de la soledat; en la segona composició, titulada «Otra (loa) a la soledad de las celda», la religiosa celebra la tornada de la seva comunitat de trinitàries (1646) al nou convent reformat després d'un any i mig d'estada a un altre convent, amb les incomoditats que va suposar (Arenal/ Sabat ed. 1988).
} 


\section{Verònica Zaragoza. Escriure poesia al convent: entre la devoció i l'obediència. Primera aproximació a un manuscrit femení del segle XVIII}

«iOh, mi amada soledad, / que bienes en ti se hallan, / pero yo apenas te gozo / cuando tengo de dejarte!». S’hi està referint sor Eulària al tòpic de la soledat anhelada, com a mitjà d'assoliment del món interior espiritual i com a requisit necessari per a la unió amb Déu i el gaudi dels béns i favors divins rebuts; en els versos següents, la religiosa expressa a Jesucrist una queixa pel fet que l'obliga a abandonar aquesta solitud i la fa allunyar-se del recer espiritual desitjat. La composició se'ns presenta propera a la interpretació autobiogràfica atés que està bastida sobre una remissió als personatges bíblics de les germanes Marta i Maria de Betània (Ll. 10:38-42), representants de la vida activa i la contemplativa respectivament. Amb aquesta referència, doncs, la religiosa sembla voler representar el doble paper que exerceix al si de la comunitat: d'una banda, com a esposa de Crist, li pertoca l'exercici de la pregària, la contemplació divina, la solitud i l'abandó de les coses mundanes en atenció de Déu; però, d'altra, el seu càrrec com a priora, l'obliga a encarregar-se del govern conventual i de les gestions econòmiques administraves. D'acord amb això, aquesta composició, sembla ser un estratagema, una fórmula justificadora de la religiosa per mostrar-se humilment davant l'exercici de priora que li conferia una plena autoritat i palesar, així, una actitud de total subjecció i obediència. Així doncs, sor Eulària defensa que allò que l'ha allunyada de la pau de la cel la només han estat les obligacions quotidianes d'administració de la comunitat pròpies del càrrec i que ella ha acceptat perquè ha estat un designi diví.

¿Quién si no vos, Jesús mío,
de la celda me ha sacado?
Que sólo es la obediencia
quien del retiro me aparta.
El alma que bien la cumpla
siempre queda aprovechada,
que dejaros a vos por vos
ya sé yo que no es dejaros.
$[. .$.
correré oficiosa
en los negocios de casa,
si en eso está vuestro gusto
venceré mi repugnancia.
No os deja quien sabe unir
a Madalena con Marta,
el que en medio del bullicio
de vuestros pies no se aparta.

Possiblement, el temor de sor Eulària a veure's involucrada en acusacions de supèrbia i els intents de convèncer i (autoconvèncer-se) que amb l'activitat literària empresa no incorria en la temptació de la vanitat, explica el to que trobem en alguna altra composició, el qual reflecteix aquella «ansiedad de autoría» (Weber 2005b: 79) present en la mateixa Teresa de Jesús i en totes les autores del període. Així doncs, al costat de la retòrica de la humilitat que inunda els textos d'una sèrie de tòpics centrats en la completa obediència al confessor i a l'Església, sor Eulària utilitza la poesia per expressar la seva angoixa davant l'acte literari i manifesta explícitament el rebuig a aquesta ordre d'escriptura imposada pel confessor, que és qui també li prohibeix l'ús de la paraula quan aquesta necessita vehicular literàriament els seus sentiments i pensaments. Observeu, doncs, el to de queixa i el grau de frustració subjacents en la religiosa quan, en la composició «Coblas que ase una alma en tiempo de sequedad, 


\section{Verònica Zaragoza. Escriure poesia al convent: entre la devoció i l'obediència. Primera}

aproximació a un manuscrit femení del segle XVIII

y obscuridad de entendimien[...], por aberselo mandado su confesor despues de mucho tiempo que se lo tenia privado» (ff. 114-120), al ludeix a la imposició dels confessors a romandre en silenci, quan té la necessitat expressiva d'escriure, i, en canvi, l'obligatorietat imposada de compondre quan, en canvi, experimenta un estat de sequera espiritual (freqüents també en la mateixa Teresa de Jesús) que li impedeix fer-ho:

\begin{tabular}{|c|c|}
\hline & $\begin{array}{l}\text { Ahora que está, Dios mío, } \\
\text { l entendimiento torpe }\end{array}$ \\
\hline 8 & $\begin{array}{l}\text { me manda vuestro ministro } \\
\text { que componga algunas coblas; } \\
\text { sólo por obedecer } \\
\text { tomo la pluma gustosa }\end{array}$ \\
\hline 12 & $\begin{array}{l}\text { y aunque no sé qué deciros } \\
\text { empiezo por vuestra gloria. } \\
\text { Imposible me parece } \\
\text { cuando está el alma indevota }\end{array}$ \\
\hline 16 & $\begin{array}{l}\text { que puede, mi amado dueño, } \\
\text { acertar a decir cosa; } \\
\text { y hallo más dificultad } \\
\text { porque veo que me imponen }\end{array}$ \\
\hline 20 & $\begin{array}{l}\text { que oculte aquello que tiene } \\
\text { mi corazón congojoso. } \\
\text { Pues dice el real profeta } \\
\text { que ha de salir por la boca }\end{array}$ \\
\hline 24 & $\begin{array}{l}\text { lo que abunda el corazón } \\
\text { pues que de ello os loquitur. } \\
\text { A mí me atan la mano, } \\
\text { como sabéis, dulce Esposo, }\end{array}$ \\
\hline 28 & $\begin{array}{l}\text { cuando por vuestra bondad } \\
\text { estoy algo fervorosa. } \\
\text { Porque a veces, Jesús mío, } \\
\text { compasivo y piadoso, } \\
\text { comunicáis a mi alma }\end{array}$ \\
\hline 32 & $\begin{array}{l}\text { sentimientos amorosos; } \\
\text { y permitís, dueño mío, } \\
\text { no le conceden entonces } \\
\text { licencia por escribirlos }\end{array}$ \\
\hline 36 & $\begin{array}{l}\text { y se lo mandan ahora. } \\
\text { Parece soy como aquellos } \\
\text { que les ofrecen que coman } \\
\text { cuando les falta apetito }\end{array}$ \\
\hline 40 & $\begin{array}{l}\text { y no pueden tragar cosa; } \\
\text { y si llego yo a cobrarle } \\
\text { solamente lo conozcan } \\
\text { me quitarán de improviso }\end{array}$ \\
\hline 44 & $\begin{array}{l}\text { lo que me ofrecen ahora. } \\
\text { No es eso queja, Dios mío, } \\
\text { sino sólo un desahogo } \\
\text { porque va la voluntad }\end{array}$ \\
\hline 48 & a vos se rinde gustosa. $[\ldots .]$. \\
\hline
\end{tabular}

Després de deixar constància de la queixa, continua, però, amb un to de subjecció a les ordres rebudes, tot encomanant-se a Déu:

No quisiera descuidarme 


\title{
Verònica Zaragoza. Escriure poesia al convent: entre la devoció i l'obediència. Primera aproximació a un manuscrit femení del segle XVIII
}

\author{
del precepto que me imponen: \\ que aunque esté con sequedad, \\ 64 escriba alegra y gozosa; \\ y aunque a mí me parece \\ que es cosa dificultosa, \\ sabéis que mi voluntad \\ 68 es de obedecer en todo. \\ Dad luz, mi querido bien, \\ a esta alma pecadora \\ pues que tiene libertad \\ 72 \\ por decir alguna cosa.
}

Aquest és un dels fragments més extraordinaris del quadern ja que reflecteix molt explícitament aquesta lluita adquirida per les religioses entre la prohibició d'escriure i la imposició de fer-ho.

En un altre ordre de coses, afirma la mateixa Atienza en l'esmentat estudi, que en les priores:

Se acentuaba esta vertiente conductual, no intelectual, en correspondencia también con las formas de aquel mundo barroco de demostraciones bien visibles y aquella religiosidad bien contrarreformista que insistía en las manifestaciones exteriores y en las demostraciones fehacientes de devoción y piedad [...] (2013: 58)

M'interessa recollir aquesta reflexió perquè en la nostra sor Eulària la seva manifestació exterior fefaent de devoció i pietat és la pròpia obra, orientada sobre el desig de perfeccionament de l’ànima (basada en l’obediència, la renúncia al món, la humilitat, el sacrifici al servei de Déu, la contrició.... $)^{27}$ i dirigida, al capdavall, a la formació moral de les lectores, les seves companyes de professió:

le poesie amorose e coniugali di una «sponsa Christi» partecipe di un cristianesimo non travagliato ma «quieto», secondo un'intenzione che a livello più alto e consapevole era anche quella degli intelletualli della Riforma; «cose piane, devote et di edificatione spirituale, et più atte a mover l'affeto che illustrare l'intelleto»(Graziosi 1996: 308).

I és que aquest manuscrit producte de l'obligatorietat imposada pels confessors també responia al desig de transmetre a les seves germanes unes formes d'espiritualitat i devocionals contrareformistes determinades, així com unes experiències vàlides per al seu perfeccionament (Barbeito 2007: 59), reforçades amb al lusions bíbliques: com ara el recurs a les paràboles de la samaritana (Jn 4:5-42) i

27 Això explica que nombroses composicions siguen planys de pecadora penedida: «Sentimientos de una alma, considerando sus pecados, y los llora a los pies de Jesu Christo» (ff. 52-55), «Coblas en que el alma se mira enferma por sus muchas culpas y busca a Dios como a medico para que la sene» (ff. 93-97)... A més a més, contínuament, en diverses composicions sor Eulària demana la intercessió de la Mare de Déu o altres sants (entre els quals Teresa de Jesús) perquè l'ajuden a aconseguir aquest perfeccionament d'ànima necessària. 
de la dona cananea (Mt 15: 21-28), així com el relat d'Adam i Eva, entre d'altres paràfrasis presents en diferents composicions.

Tal com s'esdevé amb el relat de favors espirituals (Poutrin 1995: 9), moltes de les composicions poètiques devotes que escriuen les religioses són fetes amb motius especials, generalment en festes del calendari litúrgic o en circumstàncies espirituals concretes, com ara en el context eucarístic de la Sagrada Comunió; així ho demostren les rúbriques de sor Eulària «Coblas para disponerse el alma antes de la Sagrada Comunión» (ff 7-11), «Coblas en que el alma se alegra, viendo que a de recebir en su pecho la Md. soberana de Dios» (ff. 150-152), «Coblas para dar grasias a Dios, despues de la Sagrada Comunión» (ff. 11-14), i encara, «Coblas en que se enmira el alma, de las finesas de Jesus, en dejarse sacramentado por su amon» ff. 4-7). En relació a les festes litúrgiques, en l'obra de sor Eulària trobem composicions realitzades en temps d'Advent («Coblas en las quales pide el alma a Jesus, en el tiempo de adviento que acelere su venida al mundo», ff. 63-66; «Al mismo asumto», ff. 66-67), en les festivitats de sants («Coblas echas en dia de san Agustin, considerando el alma, la constancia que tubo el santo, despues de su convercion y las muchas vezes que ella vuelve a ofender a Dios: pide misericordia y gracia para la enmienda», ff. 103-107), en el naixement de Crist («Cobla al nasimiento de nuestro Amado Redemptor», ff. 68-70; «Letra al mismo asumto», ff.. 70-72), «Coblas que ase una alma el dia de la Acension del Sr. pidiendole que le deje en predas de su amor las virtudes, para adorno de su alma» (ff. 98-100). A més a més, destaca en el quadern poètic de sor Eulària la centralitat de la humanitat de Jesucrist, l'espós, ja que gairebé totes les composicions van dedicades a capítols de la seva vida, com ara la composició en acròstic «Coblas para el dia de la circuncicion, enpesandose cada una por una letra de las que conponen los dulsisimos nombres de Jesus, Maria y Joseph (ff. 83-88). Altres composicions expressen la devoció a l'infant Jesús: «Al mismo asumpto en que pide el alma a la Virgen que le deje el Niño Jesus un pequeño rato entre sus brasos para que ensiende el corazon en su amon» (ff. 73-82); «Coblas al nino perdido» (ff. 88-90). En canvi, les composicions adreçades a la Mare de Déu són menys freqüents («Coblas a los dolores de la Virgen», ff. 109-113), per bé que és un personatge esmentat reiteradament en les composicions, a qui sor Eulària exhorta per purificar la seva ànima.

Hi trobem també una composició de lloança divina, a través de les coses creades per Déu: «Efectos que deve sacar el alma, de todo lo que Dios ha criado, alavandole en sus criaturas, y considerando que todas cunplan el fin para que las crió si no ella» (ff. 56-59). Malgrat que la doctrina palesa en les composicions de sor Eulària es basa en una renúncia al món sensible, aquesta acudeix a les criatures com a mitjà per esmentar a Déu i, de retruc, lloar-lo, atés que considera que «Y así, en todas las cosas / hallarás, si lo reparas, /motivos de dar a Dios / infinitas alabanzas. / Pide al cielo, sol y luna, / estrellas, al fuego y agua, / al viento, tierra y sus frutos / que te ayuden [a] alabarle» (f. 59), en la línia del que considerava Juan de la Cruz: «cada una de estas grandezas que se dice es Dios y todas ellas juntas son Dios» (Orozco 1989: 51). A més a més, també és interessant remarcar com el quadern poètic de sor 
Verònica Zaragoza. Escriure poesia al convent: entre la devoció i l'obediència. Primera aproximació a un manuscrit femení del segle XVIII

Eulària revela un poderós influx de la mística teresiana i, més encara, santjoanista, nodrida pel Càntic dels Càntics, ja que moltes composicions són paràfrasis directes d'aquest relat bíblic (alguns literals), que expressen l'ànsia de la unió de l'esposa amb el seu enamorat Jesucrist i la desesperació davant l'absència d'aquest. I és que, tal com és posat en relleu en relació al mestre carmelità Juan de la Cruz, la poesia dels místics també és una manera d'expressar els dubtes, l'angoixa:

\footnotetext{
Si el canto y la poesía brotan como expresión de la vida espiritual del místico no nos extrañará que constituya a veces la voz que se levanta no sólo para cantar la alabanza y gratitud al Creador, sino también para interrogar y pedir en el momento de angustia y aflicción (Orozco 1989:80)
}

Aquest to d'angoixa davant l'absència de l'espós, impregna nombroses composicions de sor Eulària: «Coblas en las quales pide el alma a su esposo sacramentado, que no venga en su interior tan disfrasado y encubierto, y que se de un poco a conoser; porque ella le sepa reverenciar como debe» (ff. 4-7), «Coblas de una alma que se queja amorosamente con Dios porque no puede amarle y se introduze con la voluntad al Cielo y pide de limosna a los vien abenturados ese Divino Amor» (ff. 100-103), «Sentimientos que de una alma que alla turbada, porque le parese que Dios se a asusentado de ella» (ff. 107-108), «Coblas en que el alma procura a resignarse en medio de sus sequedades» (ff. 123-124), «Dezimas en que el alma manda a su pensamiento que vaya en busca de su Dulze Esposo y le manifiesta el dezeo que tiene de allarle» (ff. 125-128), «Efectos de una alma que dezea hunirse con su esposo Jesus y considerando que por lograr tal dicha es presiso desprenderse de todo afecto humano, suplica a su divina Md. la desnuda de las pasiones y la bista de su grasia porque de este suerte, puede lograr vivir sola, a solas con Jesus, en lo más retirado de su corazon para irlo despues a gozar por una eternidad en la gloria» (ff- 222-227), «Coblas echas por una religiosa movida de aver leido algunos versos de los Cantares, a los quales es muy afisionada, aunque bien distante de saber himitar aquella dichosa esposa tan enamorada de Jesus» (ff. 228-248).

I ja per acabar, tal com expressa la religiosa en aquesta darrera rúbrica, algunes composicions s'originen com a conseqüència de la lectura d'algunes obres que cita en els seus versos, i això ens permet plantejar-nos el grau de formació de sor Eulària i, especialment, les influències rebudes per les lectures. Respecte a la formació de les religioses de la comunitat de Montsió, Hernández en la història del monestir elaborada, a través de la documentació de l'arxiu i la lectura de les Constitucions de la comunitat, considerava que les religioses dedicaven un lloc important a la lectura diària, per qüestions litúrgiques, ja que així ho prescrivia la Regla (1997: 106-108). Així, sor Eulària és reflectida en els seus versos com una dona culta dedicada a les lectures devotes, doctrinals, necessàries per al perfeccionament de la seva ànima, avessada sobretot a les Vides de sants, d'on treu veritats fonamentals: «Me parece, amado Esposo, / según lo que yo entiendo / que es el Pan Sacramentado / el blanco de mis deseos, pues me causa devoción, / cuando en los santos leo / que también se disponían / por llegar a vuestra mesa» (f. 27), i als quals intenta emular 


\section{Verònica Zaragoza. Escriure poesia al convent: entre la devoció i l'obediència. Primera aproximació a un manuscrit femení del segle XVIII}

en l'assoliment de les virtuts «aquí, Jesús de mi alma, / siento unos vivos deseos / para imitar las virtudes / de los santos que yo leo» (f. 28). A través de la seva poesia, sor Eulària és presenta com una fervent seguidora de santa Teresa, de la qual no s'aparta i a qui li dedica diverses composicions, algunes ja esmentades per ordre del confessor, així com unes «Dezimas a la misma Sta» (ff. 131-135) i les octaves «De las fundaciones de la sarafica Madre $\mathrm{S}^{\text {ta }}$ Teresa» (ff. 135-138), amb la qual cosa veiem que la santa d'Àvila no només va irradiar la seva influència en la tradició d'autobiografies espirituals femenines, sinó que l'influx espiritual i literari de la seva figura també és present en altres gèneres, com el poètic.

També és clau l'impacte que causa en sor Eulària la lectura de les Confessions agustinianes, en els seus exercicis espirituals, tal com li havia ocorregut a la mateixa Teresa de Jesús. En la religiosa de Montsió, ho llegim en l'esmentada composició «Coblas que escrive una $\mathrm{r}^{\mathrm{sa}}$ a quien á mandado su confesor que le explicase en unos versos los efectos que abia sentido en los diez dias de sus exercicios espirituales» (f. 28-29):

Ya sabéis, amado Esposo,
que es mi mayor consuelo,
la letura espiritual,
donde el alma se recrea;
aquí, Jesús de mi alma,
siento unos vivos deseos
para imitar las virtudes
de los santos que yo leo.
Vos sabéis, bien de mi vida,
cuantas veces me sucede
haber de dejar el libro
por lo mucho me enternezco,
y esto me sucede más
en los de santa Teresa
porque sus dulces palabras
me causan mayor afecto.
Y como en ella he leído,
que le hicieron gran provecho
las humildes Confesiones
del gran Doctor de la Iglesia,
por ese fin, Jesús mío,
he procurado tenerlas
y han causado en mi alma
muy devotos sentimientos;

\section{Conclusions}

SCRIPTA, Revista internacional de literatura i cultura medieval i moderna, núm. 1 / juny 2013 / pp. 333-361 ISSN: 2340-4841 · doi:10.7203/SCRIPTA.1.2590 
Verònica Zaragoza. Escriure poesia al convent: entre la devoció i l'obediència. Primera aproximació a un manuscrit femení del segle XVIII

Al panorama catalanoparlant, la poesia espiritual escrita per les religioses dels segles XVI-XVIII no ha estat gens explorada, generalment per la desconeixença dels textos, molts cops de difícil accés; l'estudi en aquest camp és encara més problemàtic si considerem el gruix d'obra femenina destruï, del qual només ens han arribat rastres documentals. Amb la troballa d'aquest manuscrit poètic autògraf que avui ens ha ocupat, se'ns obre la porta a un món que ens és encara desconegut, l'ambient espiritual i conventual femení d'època moderna, i ens permet començar a caminarhi amb completa normalitat, a fi de conèixer les pràctiques literàries de les dones del panorama catalanoparlant modern amb tota la seva riquesa i complexitat. 
Verònica Zaragoza. Escriure poesia al convent: entre la devoció i l’obediència. Primera aproximació a un manuscrit femení del segle XVIII

\section{Bibliografia}

Aguilar, F. (1981) Índice de las poesías publicadas en los periódicos españoles del siglo XVIII, Madrid, CSIC (Cuadernos bibliográficos, 43).

Aguirre, S. (2004) «Sonidos en el silencio: Monjas y músicas en la España de 1550 a 1650», dins John Griffiths/ Javier Suárez-Pajares (ed.). Políticas y prácticas musicales en el mundo de Felipe II, Madrid, ICCMU, pp. 285-317.

Ahumada, E. (2010) «Un espai dins del claustre: L'escriptura femenina a l'època moderna», Paraules ifets de dones, 57, p. 11.

Ahumada, E. (2013) «Hipólita de Jesús. Biografía y Bibliografía», dins Rosa M. Alabrús (ed.), La vida cotidiana y la sociabilidad de los dominicos, Sant Cugat, Arpegio, pp. 133-148.

Albert, E./ Matheu, R./ Saltor, O./ Sala, A./ Torras, M. A. (ed.) (1975) Les cinc branques: poesia femenina catalana, Engordany, Esteve Albert i Corp.

Amelang, J. (1990) «Los usos de la autobiografía: monjas y beatas en la Cataluña moderna», dins Amelang, J. S./ Nash, M. (ed.), Historia y género: las mijeres en la época moderna y contemporánea, València, Edicions Alfons el Magnànim, pp.191-212.

Arellano, I. / Vitse, M. coord. (2004) Modelos de vida en la España del Siglo de Oro, vol. II: El sabio y el santo, Madrid, Iberoamericana.

Arenal, E./ Sabat, G. ed. (1988) Sor Marcela de San Félix, Literatura Conventual Femenina: Sor Marcela de San Félix, hija de Lope de Vega, Barcelona, PPU.

Arenal, E./ Schlau, S. (2010 [1a ed. 1989]) Untold Sisters. Hispanic Nuns in Their Own Works, Albuquerque, University of New Mexico Press.

Atienza A. (2013) «Autoridad y poder en los claustros femeninos de la Edad Moderna. Las prioras dominicas vistas desde los textos normativos y ceremoniales», dins Rosa M. Alabrús (ed.), La vida cotidiana y la sociabilidad de los dominicos, Sant Cugat, Arpegio, pp. 51- 72.

Baranda, N. (2005) Cortejo a lo probibido. Lectoras y escritoras en la España moderna, Madrid, Arco Libros.

Barbeito, Ma I. (2007) Mujeres y literatura del Siglo de Oro. Espacios profanos y espacios conventuales, Madrid, M.I. Barbeito.

Bejarano, C. (2012) «Santas medievales a los ojos barrocos», Tiempos Modernos. Revista electrónica de Historia Moderna 7 /25, en línia [http://www.tiemposmodernos.org/tm3/index.php/tm/ article/viewFile/294/352] [Consulta: 16-05-2013].

Bellveser, R. coord. (2012), Dones i literatura: entre l'Edat Mitjana i el Renaixement, 2 vol., València, Institució d'Alfons el Magnànim.

Blecua A./ Serés G. dir. (2008), La Edición del teatro de Lope de Vega: las "Partes» de comedias. Criterios de edición, Bellaterra, Grupo de Investigación Prolope, Universitat Autònoma de Barcelona.

Bolufer, M. (2007) «Mujeres de letras. Escritoras y lectoras del siglo XviII», dins Rosa Ma Ballesteros

SCRIPTA, Revista internacional de literatura i cultura medieval i moderna, núm. 1 / juny 2013 / pp. 333-361 ISSN: 2340-4841 · doi:10.7203/SCRIPTA.1.2590 
Verònica Zaragoza. Escriure poesia al convent: entre la devoció i l'obediència. Primera aproximació a un manuscrit femení del segle XVIII

García, R. M./ Escudero Gallegos, C. (ed.) Feminismos en las dos orillas, Màlaga, Universidad de Màlaga, pp. 113-141.

Cátedra, M./ Rojo, Anastasio, Bibliotecas y lecturas de mujeres, siglo XVI, Salamanca, Instituto de Historia del Libro y de la Lectura.

Cerezo, J. (2012) «El libro de poesías de Marcia Belisarda. Notas al ejemplar autógrafo de la Biblioteca Nacional», Manuscrt.Cao 13, en línia [http://www.edobne.com/manuscrtcao/marciabelisarda/] [Consulta: 10-05-2013].

Collados, V. (1755) Copia de carta al assumpto del sudor, y lagrimas de Nuestra Señora del Rosario de la villa de la Guardia, del dia primero de noviembre deste año de 1755 escrita al M.R.P. Fr. Narciso de Guindos [...], Granada, Joseph de la Puerta.

Cutillas E. (1996) El Monasterio de la Santa Faz: elpatronato de la ciudad 1518-1804, [Alacant], Generalitat Valenciana. Conselleria de Cultura, Educació i Ciència/ Instituto de Cultura "Juan Gil-Albert». Diputació Provincial d'Alacant.

Díaz, J. [1759] Arte poética española: con una fertilísima sylva de consonantes comunes, proprios, esdrúxulos, y reflexos, y un divino estímulo de el amor de Dios [...]. Aumentada en esta última impressión, con dos tratados, uno de avisos, y reglas, otro de asonantes [...] con un compendio de toda el arte poética, y casi cinco mil consonantes[...], Barcelona, María Ángela Martí viuda.

Diccionari Català-Valencià-Balear, en línia [http://dcvb.iecat.net/] [Consulta: 16-05-2013].

Escartí, V. J. (2011) «Conexiones e interferencias en la literatura valenciana del siglo xv», e-Spania, 11 [=Légitimation et lignage], en línia [http://e-spania.revues.org/20384\#quotation] [Consulta: 16-05-2013].

Ferrús, B. (2004) Discursos cautivos: convento, vida y escritura, València, Universitat de València (Anejo LIII de la Revista Cuadernos de Filología).

Frenk M. (1993) «El manuscrito poético, cómplice de la memoria», Edad de Oro, 12, pp. 109-118.

Garcia, M./ Llorca, M.A. (ed.) (2012) Vides medievals de sants: difusió, tradició i llegenda, Alacant, Institut Interuniversitari de Filologia Valenciana.

Giordano, M. L. (2007) «Al borde del abismo: “falsas santas»e "ilusas» madrileñas en la vigilia de 1640», Historia Social, 57 [=Religiosidad femenina y sociabilidad barroca], pp. 75-97.

Graziosi, E. (1996) «Scrivere in convento: devozione, encomio e persuasione nelle rime delle monache fra Cinque e Seicento», dins Gabriela Zarri (ed.), Donna, disciplina, creanza cristiana dal XVI al XVII secolo. Studi e testi a stampa, Roma, Edizioni di Storia e Letteratura, pp. 303-331.

Guilhem, C. (1981) «La Inquisición y la devaluación del verbo femenino», dins Bartolomé Bennassar (ed.), Inquisición española: poder politico y control social, Barcelona, Ed. Crítica, pp. 171-207.

Haliczer S. (2002) Between Exaltation and Infamy: Female Mystics in the Golden Age of Spain, Oxford, Oxford University Press. 
Verònica Zaragoza. Escriure poesia al convent: entre la devoció i l'obediència. Primera aproximació a un manuscrit femení del segle XVIII

Hernández, M.S. (1997) Montesión, una comunidad de dominicas en Barcelona, s. XIV-XVI, 2 vol., Barcelona, Universitat de Barcelona. Tesi de llicenciatura inèdita.

Hernández, M.S. (2002) «La celda del convento, una habitación propia. La vivencia de la clausura en la comunidad de dominicas de Montesión», Duoda. Revista d'estudis feministes, 22, pp. 19-40.

Herrero, M. A. (2009) Lletraferides modernes: catàleg de les escriptores valencianes dels segles XVI-XVIII, Sant Vicent del Raspeig, Centre d'Estudis sobre la Dona/ Universitat d'Alacant.

Herrero, M. A. (2010) «Per manament del confessor: l'esclat de l'autobiografia femenina en l'edat moderna. El cas del Dietari espiritual de la il licitana sor Gertrudis de la Santíssima Trinitat», Ítaca. Revista de Filologia, 1, pp. 179-190.

Jornet, N. (2007) «Accions i reflexions en l'organiztzació d'un arxiu monàstic: el Monestir de Sant Benet de Montserrat», BiD: textos universitaris de biblioteconomia i documentació 18, en línia [http:// www.ub.edu/bid/18jornet.htm] [Consulta: 16-05-2013].

Jung, U. (2000) «Autoras barrocas de la Península Ibérica: Producción literaria femenina entre clausura, certamen poético y mercado», Notas. Reseñas iberoamericanas, 7/2, pp. 2-16.

Llansol, J. (1805) Sermón fúnebre en las solemnes exequias de la venerable sor María de Santa Clara, religiosa clarisa del convento de N. Señora de los Ángeles del lugar de Ruzafa, extra-muros de Valencia. Predicado en dicho convento día 21 de Febrero de 1805, por el R.P. Fr. Joaquín Llansol, lector jubilado, ex-definidor de la Santa recolección de la provincia oservante de $S$. Francisco y examinador synodal del arzobispo de Valencia. Sale á luz a expensas de una persona afecta a la venerable, València, Benet Monfort.

Lobato E. (ed.) (2006) Teresa de Jesús, Libro de la Vida, Barcelona, Lumen.

Luna, L. (1993) «Prólogo de autora y conflicto de autoridad», dins Leyendo como una mujer la imagen de la mujer, Barcelona/Sevilla, Anthropos/Instituto Andaluz de la Mujer, pp. 41-48.

Mazuela-Anguita, A. (2012) Artes de canto (1492-1626) y mujeres en la cultura musical del mundo ibérico renacentista, 2 vol., Barcelona, Universitat de Barcelona. Tesi doctoral [en línia: http://hdl.handle. net/2445/35622] [Consulta: 16-05-2013].

Mas, P./ Vellón, J. (1997) Literatura barroca en Castellón: María Egual (1655-1735). Obra completa, Castelló, Sociedad Castellonense de Cultura.

Miguel, F. ([1727]) Sermón fúnebre bistórico en las exequias de la venerable señora doña Gertrudis Anglesola, religiosa cisterciense y dos veces abadesa en el Monasterio de la Zaydia. Predícole el[...]16 de diciembre del año 1727 en la Iglesia del mismo monasterio Francisco Miguel[...], València, Antonio Bordázar.

Miralles, E. (2013) «Mujeres y memoria escrita en la Edad Moderna», dins Vicent Josep Escartí (coord.), Escribir y persistir. Estudios sobre la literatura en catalán de la Edad Media a la Renaixença, vol. I, Los Àngeles- California - U.S.A/Buenos Aires-Argentina, Editorial Argus-a Artes/ Humanidades - Arts/ Humanities, pp. 99-133.

Miralles, E./ Zaragoza, V. (2012) «Écrits féminins catalans. Bilan et perspectives», Clio, 35/1, pp. 177-190. 
Verònica Zaragoza. Escriure poesia al convent: entre la devoció i l’obediència. Primera aproximació a un manuscrit femení del segle XVIII

Morat, A. (1789) El espiritu de la perfección evangélica manifestado en la vida y hechos de la madre Maria Isabel Francesch y escurpí, religiosa del orden del P. Santo Domingo, en el monasterio de Ntra. Sra. de los Ángeles de Barcelona, en donde murió, año 1788 [...], Barcelona, Francisco Suriá y Burgada.

Morujão, I. (1996) «Poesia e Santidade: alguns contributos para uma percepção do conceito de santidade, a partir de duas biografias devotas de religiosas do séc. XVIII português», Via Spiritus, 3, pp. 235-261.

Olarte, M. (1993) «La 'Monjas Músicas’ en los conventos españoles del Barroco. Una aproximación etnohistórica», Revista de Folklore, 13 / 146, pp. 56-63.

Orozco, E. (1989) Poesía y mística. Introducción a la lírica de san Juan de la Cruq, Madrid, Guadarrama.

Ortí, F. (1728) Sermón fúnebre en las exequias de la V. señora $D^{a}$ Gertrudis Anglesola, religiosa cisterciense en el Real Monasterio de Nuestra Señora de Gratia Dei [...], València, Josef Garcia.

Ortí, J. V. (1743) Vida, virtudes y prodigios de la Venerable Señora $D^{a}$ Gertrudis Anglesola, religiosa cisterciense y dos veces abadesa en el monasterio de Nustra Señora de Gratia Dei, vulgo de la Zaydia, en la ciudad de Valencia [...] Que escrivia don Joseph Vicente Ortì y Mayor [...], València, Josep Tomàs Lucas.

Palacios, E. (2002) La mujer y las letras en la España del siglo XVIII, Madrid, Ediciones del Laberinto.

Paulí, A. (1952) El Real Monasterio de Nuestra Señora de Monte-Sión de Barcelona, Barcelona, [s.1.].

Peña, M. (1999) «Manipulación masculina del discurso femenino en biografías de monjas», dins Monika Bosse, Bárbara Potthast/ André Stoll (ed.), La creatividad femenina en el mundo barroco hispánico, vol. II, Kassel, Reichenberger, pp. 597-610.

Piquer J. J. (ed.) (1986), Llibre de goigs i devocions de Vallbona: atribuït a l'abadessa Jerònima de Boixadors (1554-1562), Vallbona de les Monges [s.n.].

Poutrin, I. (1995) Le Voile et la plume: autobiographie et sainteté féminine dans l'Espagne moderne, Madrid, Casa de Velázquez.

Poutrin, I. (2003) «La lecture hagiographique comme pratique religieuse féminine (Espagne, xviexvire siècles)», Mélanges de la Casa de Velárquez: Nouvelle série, 33/2 [=Le temps des saints], pp. 79-96.

Rhodes, E. (2000) «Y yo dije, sí Señor. Ana Domenge y la Inquisición de Barcelona», dins M.E. Giles (ed.), Mujeres en la Inquisición, Barcelona, Ediciones Martínez Roca, pp. 167-190.

Rodriguez, J. (1747) Biblioteca Valentina. Compuesta por el M. R. P. M. Fr. Joseph Rodriguez, Ministro del Real Convento del Remedio de Valencia, Cronista General del Orden de la SS. Trinidad en la Provincia de Aragón, València, Joseph Thomás Lucas.

Romero-Díaz, N. (2012) «Aproximaciones a la poesía secular escrita por mujeres, 1650-1700», Caliope 18 / 1, pp. 102-126.

Rubió, J. (1984-1986) Història de la literatura catalana, vol. II, Barcelona, PAM. 
Verònica Zaragoza. Escriure poesia al convent: entre la devoció i l'obediència. Primera aproximació a un manuscrit femení del segle XVIII

Sánchez, J.L. (1988) Mujeres, conventos y formas de la religiosidad barroca, Madrid, Fundación Universitaria Española.

Sánchez, G. (2011) «La música en los monasterios de monjas jerónimas a la luz de las Actas Generales de la Orden», dins Francisco Javier Campos y Fernández de Sevilla (ed.), La clausura femenina en el Mundo Hispánico: una fidelidad secular, vol. I, San Lorenzo del Escorial, Real Centro Universitario Escorial-María Cristina, pp. 945-958.

Sanhuesa, M. (2004) «Música de señoras: las religiosas y la teoría musical española del siglo XVII», dins Francisco Javier Campos y Fernández de Sevilla (ed.), La clausura femenina en España. Actas del simposium: 1/4-IX2004, vol. I, El Escorial, Real Centro Universitario Escorial-Maria Cristina, pp. 167-180.

Trias, S. (ed.) (1988) Anna Maria del Santíssim Sagrament, Càntics i cobles, Palma, Moll.

Weber, A. (2005a) «Autobiografías por mandato:¿Egodocumentos o textos sociales?», Cultura escrita y sociedad 1, pp. 116-119.

Weber, A. (2005b) «El feminismo parcial de Ana de San Bartolomé», dins Lisa Wollendorf (ed.), Literatura y feminismo en España: (s. XV-XXI), Barcelona, Icaria, pp. 77-94.

Zaragoza, V. (2010a) «Posà-la per ser humil en la montanya més alta». La literatura femenina a l'edat moderna a Catalunya $i$ a les Illes Balears, Girona, Universitat de Girona. Treball de màster inèdit.

Zaragoza, V. (2011) «La permeabilitat de la clausura: el convent dels Àngels a la Barcelona del segle XVII i l'obra de Contesina Fontanella», comunicació presentada al XII Congrés d'història de Barcelona. Historiografia barcelonina. Del mite a la comprensió (Barcelona, 30 novembre-1 desembre 2011), Barcelona, AHCB, [en línia: http://w110.bcn.cat/ArxiuHistoric/Continguts/ Documents/Fitxers/Comun02 Zaragoza.pdf].

Zaragoza, V. (2012) «Historiar les protagonistes absents. La poesia femenina de l'edat moderna a l'àmbit català», comunicació presentada al I Congrés «Aula Música Poètica»: Trobada de Joves Humanistes (ss. XVI-XVII i XVIII), (org. Grup de recerca 'Aula Música Poética' (Universitat de Barcelona) (Barcelona, 9-10 octubre 2012) [en premsa] 